\title{
BioéthiqueOnline
}

\section{Dilemmas in Military Medical Ethics: A Call for Conceptual Clarity}

\section{Christiane Rochon}

Volume 4, 2015

Reçu : 17 Mar 2015; publié : 17 Dec 2015; éditeurs : Vanessa Chenel \& Charles Dupras; évaluateurs externes : Leslie London \& Michael L. Gross

URI : https://id.erudit.org/iderudit/1035513ar

DOI : https://doi.org/10.7202/1035513ar

Aller au sommaire du numéro

Éditeur(s)

BioéthiqueOnline

ISSN

1923-2799 (numérique)

Découvrir la revue

Citer cet article

Rochon, C. (2015). Dilemmas in Military Medical Ethics: A Call for Conceptual Clarity. BioéthiqueOnline, 4. https://doi.org/10.7202/1035513ar
Résumé de l'article

Malgré l'augmentation des conflits armés et des changements qui les caractérisent, les enjeux éthiques auxquels font face les médecins militaires sont très peu traités dans la littérature en bioéthique. Les médecins militaires sont des membres du corps militaire, même s'ils sont non combattants, et ils jouent un rôle de soignant tout en pouvant être appelés à agir comme aide humanitaire. Certains auteurs se sont même interrogés sur la compatibilité morale d'être à la fois médecin et soldat. Les conflits éthiques soulevés dans la littérature sur les médecins militaires peuvent être organisés autour de trois perspectives : 1) les problèmes moraux en médecine militaire seraient particuliers compte tenu des difficultés à respecter les principes bioéthiques traditionnels; 2) les codes d'éthique médicaux et les lois internationales seraient trop restrictifs ou inadéquats pour le contexte militaire; et 3) les médecins sont des acteurs sociaux qui devraient être pacifistes, défenseurs des droits de la personne, politiquement neutres ou promoteurs de la paix. Une revue des divers dilemmes rencontrés par les médecins militaires identifiés dans la littérature nous montre que ces perspectives se situent à des niveaux d'analyse différents (micro, méso, macro), que les contextes et les acteurs impliqués sont souvent différents et que les dilemmes vont bien au-delà des enjeux liés strictement à l'intérêt du patient. Tout comme la profession médicale en général, la médecine militaire est complexe et soulève des points de vue divergeant quant au rôle et aux obligations du médecin. Une plus grande clarté des concepts employés dans les discussions autour de l'éthique médicale militaire apparaît donc nécessaire.
Ce document est protégé par la loi sur le droit d'auteur. L'utilisation des services d'Érudit (y compris la reproduction) est assujettie à sa politique d'utilisation que vous pouvez consulter en ligne.

https://apropos.erudit.org/fr/usagers/politique-dutilisation/ 


\title{
Dilemmas in Military Medical Ethics: A Call for Conceptual Clarity
}

\author{
ARTICLE (RÉVISION PAR LES PAIRS / PEER-REVIEWED) \\ Christiane Rochon ${ }^{1}$ \\ Reçu/Received: 17 Mar 2015 \\ Publié/Published: 17 Dec 2015 \\ Éditeurs/Editors: Vanessa Chenel \& Charles Dupras \\ Évaluateurs externes/Peer-Reviewers: Leslie London \& Michael L. Gross
}

2015 C Rochon, $\underline{\text { Creative Commons Attribution 4.0 International License }}$

\section{Résumé}

Malgré l'augmentation des conflits armés et des changements qui les caractérisent, les enjeux éthiques auxquels font face les médecins militaires sont très peu traités dans la littérature en bioéthique. Les médecins militaires sont des membres du corps militaire, même s'ils sont non combattants, et ils jouent un rôle de soignant tout en pouvant être appelés à agir comme aide humanitaire. Certains auteurs se sont même interrogés sur la compatibilité morale d'être à la fois médecin et soldat. Les conflits éthiques soulevés dans la littérature sur les médecins militaires peuvent être organisés autour de trois perspectives: 1) les problèmes moraux en médecine militaire seraient particuliers compte tenu des difficultés à respecter les principes bioéthiques traditionnels; 2) les codes d'éthique médicaux et les lois internationales seraient trop restrictifs ou inadéquats pour le contexte militaire; et 3 ) les médecins sont des acteurs sociaux qui devraient être pacifistes, défenseurs des droits de la personne, politiquement neutres ou promoteurs de la paix. Une revue des divers dilemmes rencontrés par les médecins militaires identifiés dans la littérature nous montre que ces perspectives se situent à des niveaux d'analyse différents (micro, méso, macro), que les contextes et les acteurs impliqués sont souvent différents et que les dilemmes vont bien au-delà des enjeux liés strictement à l'intérêt du patient. Tout comme la profession médicale en général, la médecine militaire est complexe et soulève des points de vue divergeant quant au rôle et aux obligations du médecin. Une plus grande clarté des concepts employés dans les discussions autour de l'éthique médicale militaire apparaît donc nécessaire.

\section{Mots clés}

médecins militaires, conflits des rôles, éthique médicale, éthique professionnelle, codes de déontologie, dilemmes

\section{Abstract}

Despite the increase in and evolving nature of armed conflicts, the ethical issues faced by military physicians working in such contexts are still rarely examined in the bioethics literature. Military physicians are members of the military, even if they are non-combatants; and their role is one of healer but also sometimes humanitarian. Some scholars wonder about the moral compatibility of being both a physician and soldier. The ethical conflicts raised in the literature regarding military physicians can be organized into three main perspectives: 1) moral problems in military medicine are particular because of the difficulty of meeting the requirements of traditional bioethical principles; 2) medical codes of ethics and international laws are not well adapted to or are too restrictive for a military context; and 3) physicians are social actors who should either be pacifists, defenders of human rights, politically neutral or promoters of peace. A review of the diverse dilemmas faced by military physicians shows that these differ substantially by level (micro, meso, macro), context and the actors involved, and that they go beyond issues of patient interests. Like medicine in general, military medicine is complex and touches on potentially contested views of the roles and obligations of the physician. Greater conceptual clarity is thus needed in discussions about military medical ethics.

\section{Keywords}

military physicians, conflict of roles, medical ethics, professional ethics, codes of ethics, dilemmas

\section{Exonération}

Les évaluations des examinateurs externes sont prises en considération de façon sérieuse par les éditeurs et les auteurs dans la préparation des manuscrits pour publication. Toutefois, être nommé comme examinateur n'indique pas nécessairement l'approbation du manuscrit par cet examinateur. Les éditeurs de BioéthiqueOnline assument la responsabilité entière pour l'acceptation finale et la publication d'un article.

\section{Disclaimer}

Reviewer evaluations are given serious consideration by the editors and authors in the preparation of manuscripts for publication. Nonetheless, being named as a reviewer does not necessarily denote approval of a manuscript by the reviewer; the editors of BioéthiqueOnline take full responsibility for final acceptance and publication of an article. 
Affiliations des auteurs / Author Affiliations

${ }^{1}$ Consultant, Montréal, Canada

\section{Correspondance / Correspondence}

Christiane Rochon, christianerochon@hotmail.com

\section{Remerciements}

Je suis reconnaissante envers les professeurs Bryn Williams-Jones et Matthew Hunt pour leurs suggestions et commentaires constructifs sur plusieurs versions de cet article. Une version précédente a été présentée au Points of Intersection Ethics, Rights, Health Care \& Public Health in Humanitarian Assistance conference à Hamilton, Ontario, en 2010, et l'article a bénéficié grandement des commentaires de l'audience de cet évènement. Plusieurs des idées présentées ont progressé grâce aux discussions avec les membres du Groupe de recherche sur l'éthique en médecine militaire. La recherche pour cet article a été rendue possible grâce à une bourse d'étude de la part des Fonds de recherche sur la société et la culture (FRQ-SC), et du financement de Bryn Williams-Jones, Lisa Schwartz et Matthew Hunt par le Bureau d'éthique des Instituts de la recherche en santé du Canada (IRSC).

\section{Conflit d'intérêts}

L'auteure confirme qu'elle n'a aucun intérêt financier ou autre connexion, directe ou indirecte, ou autre situation qui pourrait soulever des questions de biais dans le travail rapporté ou les conclusions, implications ou opinions résultant de cet article. Les études doctorales de l'auteure ont été supervisées par Bryn Williams-Jones, Éditeur en chef de BioéthiqueOnline.

\section{Acknowledgements}

I am grateful to professors Bryn Williams-Jones and Matthew Hunt for their constructive comments and suggestions on various drafts of this article. An early version of this paper was presented at the Points of Intersection Ethics, Rights, Health Care \& Public Health in Humanitarian Assistance conference in Hamilton, Ontario, in 2010, and benefited greatly from the audience feedback. Many of the ideas here benefited from discussions with members of the Ethics in Military Medicine Research Group. The research for this article was supported by a scholarship from the Quebec Fonds de recherche sur la société et la culture (FRQ-SC), and funding to Bryn Williams-Jones, Lisa Schwartz and Matthew Hunt from the Ethics Office of Canadian Institutes of Health Research (CIHR).

\section{Conflicts of Interest}

The author confirms there are no financial interests or connections, direct or indirect, or other situations that might raise questions of bias in the work reported or the conclusions, implications, or opinions stated in the present article. The author's PhD was supervised by Bryn WilliamsJones, Editor-in-chief of BioéthiqueOnline.

\section{Introduction}

Western militaries are now strongly mobilized by threats and conflicts. The tension between the great powers, characteristic of the Cold War, has been replaced by a proliferation of intrastate conflicts and terrorist acts; while the conflicts have changed in nature, security remains at the heart of Western foreign policy. The work of health professionals in such conflicts has garnered significant public and academic interest. For example, in the United States, Miles [1] denounced the involvement of some physicians in hostile interrogations of prisoners, while Allhoff [2] raised questions about the ethical duties and obligations of medical officers.

The literature on military medicine shows diverse points of view regarding potential ethical tensions or dilemmas. For some, military physicians are first and foremost health professionals and so should only consider their patient's welfare in their decision-making; i.e., they should give primacy to traditional bioethics principles (e.g., autonomy, beneficence, non-maleficence, justice) over other values [3,4]. For others, these principles are difficult to apply in a context where collective needs namely security issues and scarce resources - must be addressed [5-7]. Some scholars consider the main ethical challenge to be that military physicians have dual loyalties, having obligations both towards their patients and their employers [2,8-10]. Military physicians are members of two professions, each with it's own distinct (and potentially conflicting) ethical codes, norms and values. Other scholars raise the question about a physician's legitimate role in war, asserting that as medicine is a pacifist and apolitical profession, physicians should only be involved in providing care and should ideally promote peace [11,12]. Finally, some even consider the military profession to be so different from that of healthcare that the two are considered totally morally incompatible [11].

Military medical ethics is a subject that highlights a series of concepts that are often studied in theoretical and isolated terms, such as double/dual loyalties, medicine as a profession, public health 
policy, and the responsibility of healthcare professionals towards society. One of the main problems in the literature regarding military medical ethics, I suggest, is that questions and dilemmas are often examined independently - as if they are not in fact interrelated - and resulting from opposition with a military perspective. For example, dilemmas for physicians in the military are thought to come mainly from the tension between military and patient interests, where such opposition diverts military physicians' focus away from patient interests and towards issues such as military necessity. However, the concept of military necessity - an important principle in international humanitarian law that aims to circumscribe the legal and justified use of force in armed conflict and one that evolves in accordance with human rights and humanitarian values [13] - is rarely defined by scholars and is often treated as synonymous with military interest. Further, stereotypical judgments are often implied with regards to medicine which tends to be idealized while the military is presented mostly in negative terms and as having opposite values to those of physicians or with antiwar sentiments $[14,15]$. Even more problematic is the fact that some of the issues or dilemmas discussed in the literature differ in important ways with regards to the perspective of the actors involved, and thus the level of ethical analysis that is required: individual (micro), institutional (meso), or social/political (macro). So, for example, ethical dilemmas can be examined either through the lens of the physician-patient relationship; or via considerations of deontological issues, such as conflicts between different professional duties and obligations (professional codes of ethics or international humanitarian laws); or through discussion of broader dilemmas concerning the physician's role towards society in general and in war in particular. But to treat all of these issues as if they were problems of the same order or nature - and thus requiring similar ethical considerations - is to misunderstand the complexity of the context in which military physicians operate.

This article presents the main issues discussed in the military medical ethics literature and suggests that they can be grouped under three analytical perspectives that are often discussed in isolation from one another, hence neglecting important elements and concepts. The goal is to provide greater clarity regarding what should be considered when studying ethical issues in a context such as the military institution, where individual and collective interests can create important conflicts. There is clearly more to the work of a military physician than just an opposition or tension between two actors: physicians and the military institution or patient interest and the common good. Military physicians have a diversity of roles and obligations at different levels towards their patients, their employers and to the society that they serve. Military culture and physicians' values, but also professional rules and political and social choices, are all elements that combine to define or constrain ethical choices in a given context.

The analysis of ethical conflicts or dilemmas in military medicine must involve more than a micro-level perspective - i.e., that of the ethical physician - because meso and macro level issues and interests shape the practice and work environments of military (and other) physicians. Greater conceptual clarity is thus needed in discussions about military medical ethics in order to recognise the complexity of the relationships between the diverse stakeholders involved (i.e., physicians, patients, military institutions, and society in general). While ethical responsibility for patient care may ultimately lie on the shoulders of physicians, they are not the only or primary ethical agent in military medicine; this responsibility can and should be shared with other key stakeholders (e.g., the military institution) to ensure the practice of an ethical military medicine.

\section{Ethical dilemmas in military medicine}

Sidel and Levy [11] conducted a comprehensive review of the ethical tensions that military physicians faced in the US military. More recently, Gross [16] addressed the non-clinical challenges faced by physicians in the military, discussing the participation of physicians in the development of non-lethal weapons, in medical experimentation and research on enhancement technologies, and in humanitarian activities. Gross [16] points to the complexity of issues in military medicine, but also and perhaps more importantly, to the fact that there is a climate of mistrust between the military and the 
scientific community in general, and with bioethics in particular; it is as if discussing issues about the (in)appropriate involvement of physicians in military activities promoted a "misguided, wrong and dangerous" political agenda [17, p.10].

Without going into a complete description of all the ethical conflicts or dilemmas raised in the literature - each of which could be the subject of a lengthy description and analysis - I suggest a classification to show that most are generally presented from three (distinct) points of view (see Figure 1):

1. Moral problems in military medicine are particular because of the difficulty in giving primacy to traditional bioethics principles;

2. Medical codes of ethics and international laws are too restrictive and not adapted to a military context, and so do not provide the necessary guidance to make ethical decisions;

3. Physicians are social actors working within institutions, but should be pacifists, defenders of human rights, politically neutral or promoters of peace.

Obviously, the presentation of the dilemmas and discussions about the ethics of military medicine are not as sharp as the figure may suggest. But this classification allows us to see where the arguments are generally situated when we are dealing with a particular type of dilemma. Although for analytical purposes we sometimes need to limit our perspective to one element - whether clinical, deontological social or political - it is still essential to keep in mind that all of these elements constitute the reality of military physicians. This classification shows how dilemmas can be sorted for analysis, but ultimately all of these roles and conflicts are potentially within the same individual, that is, the military physician. The classification also shows that ethical responsibility is shared between physicians, the military institution, professional associations, and society which through their government also defines the role and contribution of physicians in the military.

The types of dilemmas - and the different arguments and perspectives of scholars who have reflected on these situations - are situated at different levels, i.e., individual (micro), institutional (meso), or social/political (macro) and focus on different contexts and stakeholders. Moreover, they address different roles and obligations that physicians have to play as healers, professionals, employees and social actors. Some of the issues are therapeutic in nature (care of patient), while others are more social and political (e.g., participation of physicians in the war effort or identification of who are to be categorized as combatants). This results in ethical dilemmas often being examined either through the lens of the physician-patient relationship, which opposes the patient's welfare with military interest; or via considerations of legal issues, such as conflicts between different legal and professional duties and obligations (international humanitarian law and professional codes of ethics); or finally through discussion of broader dilemmas concerning the physician's role towards society in general. Treating all of these issues in the same way can put enormous pressure and responsibility on physicians, as if they were responsible not only for their own actions, but also for establishing an ethical climate in the institutions in which they work, and even in society more generally. Physicians certainly have a role to play in this regard, but they obviously cannot and should not bear all these responsibilities alone. 
Figure 1: Types of Ethical Dilemmas in Military Medicine

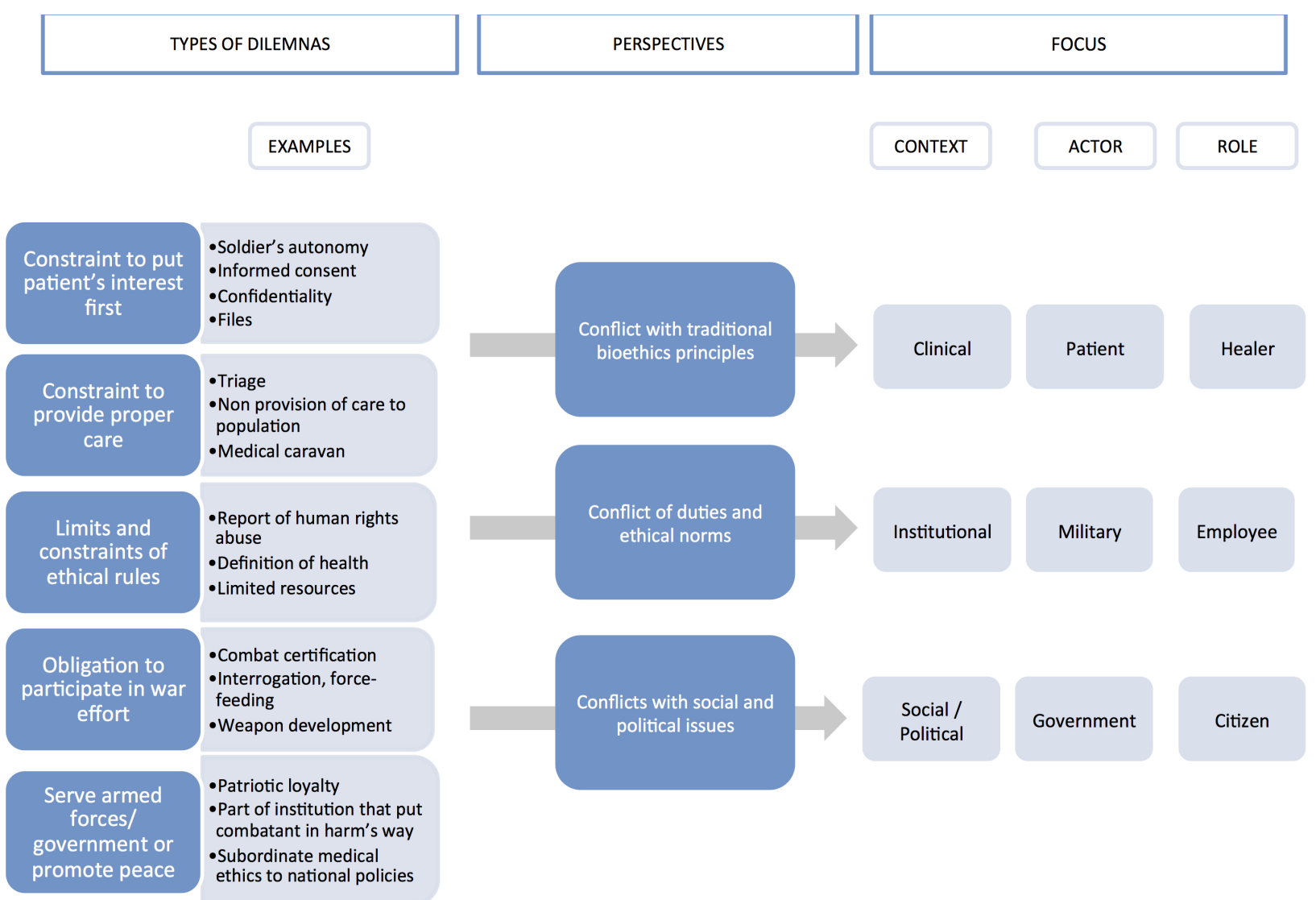

\section{Conflict with traditional bioethics principles}

The four principles of autonomy, beneficence, non-malfeasance and justice have been for some time at the heart of North American bioethics. Concern for the patient's wellbeing and interests, together with the primacy of doing no harm, are seen as ethical principles that should always guide medical practice $[3,4]$. According to some authors, in a military context these principles are impossible to respect, making it "morally unacceptable" for a physician to be both a physician and a soldier [11]; an opposition is created between the patient's rights and the common good, with health professionals having to privilege the former over the latter. But other scholars argue that bioethics needs to find a balance between these two objectives [18] hence a move towards focusing more on issues of justice and equality [19].

Gross [5] explains that a soldier's autonomy is always limited in a military context, since the right to life, for example, is voluntarily delegated, at least in part, to the military institution by the soldiercombatant. Unlike a civilian, a soldier cannot refuse treatment or vaccination and so expects to be treated primarily with a view to return to combat. As Bloche [7, p.273] points out, "patients are themselves committed to the social purpose served by medical intervention". During armed conflict where there are specific rules to follow, a strict hierarchy and an established chain of command - the patient-physician relationship becomes fairly paternalistic [20]. In a context where soldiers are legitimately sent into dangerous and potentially deadly situations, the principle of informed consent, which is a fundamental basis of the physician-patient relationship in Western countries, can also be difficult to apply $[5,21]$. For example, in the US, the requirement for informed consent can be overridden in certain combat situations by the US Department of Defense invoking Article 23(d) of the Food, Drug and Cosmetic Act [22). This exception applies to mandatory protections of soldiers, such as vaccination - but not experimentation - and gives the military "the authority to compel service members to take certain drugs to protect themselves" [22, p.863]. 
In the same way, the principles of privacy and confidentiality within the physician-patient relationship, closely linked to respect for autonomy, also become more problematic in the military context. For example, because of the threat posed by certain patients, mainly detainees, physicians must exercise caution to protect themselves while treating and talking with patients. Hence, military personnel may be present during diagnosis and care, thus potentially breaching patient privacy and confidentiality. In the case of prisoners, in the "war on terror" some military physicians even disclosed confidential medical information about prisoner-patients to US intelligence personnel [1,23]. It was also reported that injured (allied or enemy) soldiers have been filmed, without their consent, by the media or the military, either to demonstrate the horrors of war or for reasons of propaganda [24]. As Sidel and Levy note [11], there have also been problems with the management of the medical files of soldiers and non-combatants. ${ }^{1}$ Negligence in medical records keeping was reported for prisoners in Iraq and Afghanistan, where death certificates of detainees were found to be incomplete or even falsified [25].

Such dilemmas also occur in other clinical settings, such as breaches of confidentiality in the case of child abuse or the obligatory declaration of infectious diseases; but many authors argue that the magnitude of these dilemmas is amplified in the military context, in part due to the level of risk, stress and pressure for the key actors to support military objectives [23]. According to Sidel and Levy [11], these types of dilemmas arise primarily because physicians are required to subordinate their patients' best interests and wishes to that of military necessity. Arguably, in such a context, traditional ethical principles do not provide a comprehensive or sufficient practical guide for medical personnel $[5,6,26]$. Within this perspective, clinical context and patient interest are the main preoccupation and so a physician's primary role and activity are viewed as that of a healer with strictly therapeutic aims. But limiting the analysis to the clinical role with one patient disregards the fact that military physicians must also maintain a unit's health, have to deal with important resource limitations, and sometimes even national policies that affect their work.

\section{Conflict of duties and ethical norms}

Gross [5] highlights the ethical tensions that arise from the World Medical Association (WMA) declaration [27] that medical ethics is the same in peacetime as in war, and the Geneva Convention Physician's Oath [28] adopted by the WMA, that requires physicians to affirm that "the health of my patient will be my first consideration". In this case, potential tensions relate to codes of conduct that do not take into account outside pressures, both in the patient-physician relationship and between physicians and the institution (i.e., principles of necessity or military interest). From this perspective, conflict arises in military medicine from tensions between professional duties. These dilemmas are closely linked to the first category, i.e., conflict with traditional bioethics principles, and also concern about the physician-patient relationship, but are generally presented with an emphasis on the relationship between physicians and their host institutions, and the fact that military physicians may have multiple obligations and ethical codes to which they should refer. Authors such as Sidel and Levy [11], Gross [5], Miles [29] and Hathout [30] argue that for reasons of military necessity, physicians may not be able to provide appropriate care or are required to engage in practices to support military actions (e.g., interrogation of detainees, development of biological weapon or non treatment) that are contrary to the principle of non-malfeasance.

These sometimes conflicting duties and codes can create dilemmas that may be difficult for military physicians to resolve; described as an issue of 'dual loyalty' $[8,9]$ or mixed agency $[11,21]$ the aim is to highlight the tension for physicians of having to balance responsibilities to their patients and to the common good [8]. To which institution or profession do physicians owe primary allegiance? Which professional code of ethics should guide their behaviour?

\footnotetext{
${ }^{1}$ In 1996, the US Presidential Advisory Committee on Gulf War Veterans' Illnesses criticized the US military for poor record keeping; the Committee identified problems with missing medical records and the absence of or incomplete data on health effects for troops who received the anthrax vaccine during the first Gulf War, which subsequently affected soldiers' medical care when they experienced side effects.
} 


\section{Constraints to the provision of care}

Article 12 of the Geneva Convention I [31] states that triage should follow emergency medical needs, whether for one's own soldiers or for enemy soldiers/combatants. Gross $[5,32]$ argues that triage should instead be understood as a function of military necessity and thus the least injured soldiers are those who should be treated first so they can be quickly returned to battle. Some authors argue that it is normal and appropriate for armies to prioritise the treatment of their own soldiers [33]. In the US Army, the decision on how to triage is the responsibility of military commanders, after consulting with physicians [21], and so ultimately it will be the collective interest that takes precedence over individual patient interests [34].

In the Canadian Armed Forces, triage decisions are taken by a medical officer who can more freely apply medical and humanitarian ethics principles. Rawling [35] argues that the view that medical treatment of the wounded in the Canadian Armed Forces is focused primarily on return to combat is more of a cliché than an actual policy, because nothing was ever put in place to implement such a policy. In his historical review of Canadian military medicine, Rawling [35] shows that medical teams usually decided when and how they treated the wounded with little interference from military authorities. For example, from a total of 2,599 trauma patients that were seen in the Role III hospital in Kandahar, Afghanistan, between October 2009 and December 2010, almost half $(1,192)$ were Afghan troops or civilians [36]. Rawling further argues that the practice of amputation procedures and evacuation measures during conflict, which are done to save a soldier's life even if the soldier will become unfit for combat, demonstrate that triage and care are not done strictly for reasons of returning soldiers to combat. More recently in the context of the Afghanistan war, other authors have argued that triage was not the main ethical issue, as much as the difference in standards of care between NATO and Afghan soldiers who needed to be transferred to local hospitals after being treated for their trauma injuries [37-39].

Another example of dilemmas arising from conflicting duties that are discussed in the literature is when, for various reasons (e.g., because of security concerns or rules of engagement), physicians cannot provide care to local populations even if the Geneva Convention (Protocol II, article 7) stipulates that they should [40]. Physicians and other health professionals in the military can also be required to participate in "care caravans" as part of tactical agendas of "winning hearts and minds", but without being able to provide follow-up care [15].

\section{Participation in warfare}

According to Annas [4], in the US "war on terror", military physicians have faced three major challenges regarding their medical ethics, by being ordered by commanding military officers to 1) assist in intense interrogations of suspected terrorists, 2) participate in the forced feeding of prisoners on hunger strike, and 3) certify, against their own medical judgement, the ability to return to combat of soldiers being redeployed to Iraq or Afghanistan. These are, for Annas, conflicts involving professional duties that are addressed in professional codes of ethics and international humanitarian law (e.g., torture and inhumane treatment, including force feeding of detainees, are unethical behaviour in the WMA Declaration of Tokyo). But as Okie [41] and Gross [16] point out, not all bioethicists agree about force feeding, and some argue that a patient's best interest (i.e., access to life-saving treatment) should take precedence over respect for autonomy (i.e., right to refuse treatment).

Medical knowledge and services can also be used in the war effort by the military institution, thereby "weaponizing medicine" [42]. The WMA considers that physicians ought to be prohibited from participating in the development of lethal weapons, but although contentious, physician involvement in the development of non-lethal weapons that can augment a military's capabilities is occurring $[16,43]$. Questions about the role of physicians in developing strategic interrogation plans for detainees [44], non-lethal weapons to disorient the enemy [6], or tests of drugs that could genetically enhance soldiers performance in order to inhibit fear or guilt while also reducing the occurrence of Post Traumatic Stress Disorder [43] go beyond what Bloche [7, p.273] calls a "mediation between clinical 


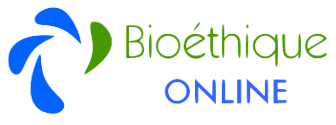

fidelity and medicine's social purposes" and should thus also be a matter of ethical reflection on the part of the military institution and healthcare professionals.

\section{Limits of or contradiction between ethical codes or laws}

Obligation conflicts can be transformed into ethical conflicts when the physician faces a situation regarding human rights. Indeed, in situations of armed conflict, health professionals are involved as non-combatants in caring for wounded soldiers (enemy or allies) and civilians. International humanitarian laws impose these roles and obligations on health professionals, and in return, grant them protection against attack [44]. When military physicians treat detainees that appear to have been the victim of mistreatment, as health professionals they have a duty to report to their superiors and other authorities these situations as cases of human rights abuse; i.e., Article 3 of the WMA Declaration of Tokyo 1979 stipulates that physicians have to report a breach of the Geneva Conventions. This requirement to report human rights abuse can create conflict between the physician and the military institution [40].

The Universal Declaration of Human Rights (UDHR) [45] provides a very broad perspective with regards to health (Article 25) and the right to life and security (Article 3), which creates expectations about the ethical treatment of civilians, soldiers and prisoners of war. Indeed, UDHR makes life, liberty and security fundamental rights of individuals, along with a right to a minimum standard of living for a person's health and well being. These rights are to be maintained during armed conflict and go hand in hand with other laws regulating conflict. As noted by the United Nations:

As a result of efforts to ensure effective protection for the rights of all persons in situations of armed conflict, a number of United Nations bodies and organizations, human rights special mechanisms, as well as international and regional courts, have in practice increasingly applied obligations of international human rights law and international humanitarian law in a complementary and mutually reinforcing manner. [46, p.118]

So in some cases, military physicians may refer to international humanitarian law when refusing to obey what they consider to be an illegal order, or one that goes against their professional medical and ethical obligations. Physicians may thus already be equipped to resolve some dilemmas, particularly those with regards to abuse, torture or involvement in developing biological weapons, since these are illegal acts under international law.

Yet, legal rules (codes of ethics, international humanitarian laws, etc.) do not always provide clear answers to physicians, and may even be contradictory. Military physicians can be caught between considerations of military interest, human rights, medical ethics principles and international rules, and a patient's well being. In the case of mass casualty situations, for example, decisions cannot simply be based on the ethical principle of non-discrimination of care as stipulated by medical codes of ethics. Medical resources (personnel and equipment) are limited, so selection may thus not be based on priority of care but on the need to save the greatest number, which may then involve neglecting the more severely wounded. Any form of triage in such a context requires physicians to exercise their own professional ethics, and not necessarily one that is solely or primarily aligned with their medical code of ethics [47]. Professional ethical rules can then create a type of dilemma, one in which legal aspects (social) conflict with ethical aspects (moral), so that "in the conflict between ethics and law, it is the conscience of each physician who arbitrates and commands certain behaviour" (translation) [48, p.118].

International laws exist to prevent excess or misdeeds during conflicts and so protect civilian populations. But the context of contemporary military medicine has changed, not only in terms of values (protection of human rights vs. sovereignty of nations) but also because the majority of conflict victims $(90 \%)$ are now civilians $[49,50]$. As conflicts have become increasingly complex in nature and 
scope, so too have the laws surrounding these conflicts. In a given situation, hundreds of legal provisions (national and international) may be relevant, only some of which will be directly applicable and able to deliver practical medico-military solutions that respond to both strategic and tactical imperatives while also being consistent with general principles of the laws of war or armed conflict; mere common sense or superficial knowledge of key international texts and conventions will be insufficient [48]. This perspective highlights the different obligations of military healthcare professionals that includes a concern for public health and the common good and thus often favours a utilitarian approach. Physicians' roles must be examined, not only in relation to their patients but also as employees within an organization and as professionals, both medical and military. It also shows the diversity of norms and ethical rules (and their complexity) to which physicians must refer. Within this perspective, we start to see how the military institution as well as professional associations have responsibilities in fostering an ethical climate and facilitating ethical reflection for military physicians (and health professionals more generally).

\section{Conflict with social and political roles}

The political philosophies adopted by many democracies set out principles of "just war" that give importance to collective interests, subordinate individual interests and thus create tensions between individual rights and those of society as a whole [5]. The doctrine of just war as a moral foundation or justification for conflict can be divided into two parts: jus ad bellum, which covers the right to resort to war, and jus in bello, which covers justice during war. However, in the ethics literature on military medicine, there is a tendency to conflate these two principles.

For military physicians, tensions could arise between a moral obligation to help in the war effort and the "pacifist nature" of the profession (principle of non-malfeasance) [51]. For example, Article VII of the American Medical Association (AMA) Principles of Medical Ethics [52], the preamble to the Code of Medical Ethics, states that "A physician shall recognize a responsibility to participate in activities contributing to the improvement of the community and the betterment of public health." For several authors [52-54], war is an activity that goes against this principle; health professionals should thus act as politically neutral moral agents and refuse to tolerate or participate in wars or conflict, situations that invariably cause significant harm to population health and to the environment. Some scholars even call upon health professionals to promote peace through health activities, because peace and health are seen as motivated by the same values; health professionals should thus work together with peace workers and institutions who have the mandate to negotiate conflict resolution [56]. Specific examples include those proposed by Levy and Sidel in their book War and Public Health [54], where they apply a public health prevention model to war because war constitutes a threat to public health [57,58], and so can and should be prevented and/or treated as are other chronic illnesses [59]. Although marginal, the pacifist school argues for physician activisms against war while other scholars argue for political activism to report human rights abuses [60].

But as Gross [16, p.97] argues, "contributing to war, no less than contributing to peace, may also distance medical workers from their primary obligations." Rascona [61], for his part, argues that wars have taken place for centuries without the assistance of physicians and their absence did not necessarily help the world to live without war. Like Gross [51], Rascona [61, p.322] questions "the notion that medical ethics may be somehow superior to (all) others." Madden and Carter [14], further argue that health professionals have, as part of the social contract that is at the base of most formal professions, a duty to "give back" to their society.

In this context, the question of physicians' legitimate participation in war does not arise from their professional obligations, but rather because of their civic obligations. Physicians who choose to work in the military can hardly resist or defy principles that were adopted by their own society with regards to just war and the use of force (which refers to the principle of jus ad bellum, or the right justification to go to war). As health professionals, physicians have a moral duty towards their patients. As citizens and members of the military, they also have a duty and obligation towards the society in which they 
live. However, their participation in war, as with all soldiers (whether or not they are combatants), is governed by the principles of jus ad bello which provides that "acts of war must be proportionate to the objectives and must respect the immunity of non-combatants, which means sparing the civilian populations" (translated) [62]. As with just war theory, which distinguishes between the right of a country to participate in war and how to act during war, it is thus important to recognise the distinction between a physician's participation in war (political neutrality or activism) and the way he or she contributes (medical neutrality), which are not equivalent [60].

Another problem for physicians relates to political decisions during conflicts. It is increasingly the case that enemy combatants are not the soldiers of an enemy state (e.g., members of a standing army), but instead are members of guerrilla, revolutionary or terrorist groups, and in some cases they are children. Are such combatants to be seen as "enemy soldiers" and thus, when captured, treated as prisoners of war and protected by the Geneva Conventions [63]? Or, following the US policy implemented by former President George W. Bush, should these combatants be treated not as soldiers, but as "unlawful combatants" and deprived of the protection they would normally receive as prisoners of war [10]?

Since AI Qaeda was not a signatory of international conventions, the US government under the Bush administration concluded that the Geneva Conventions did not apply; the principles of the Conventions only need be respected "to the extent appropriate and consistent with military necessity" [64]. While this position was hotly contested by other NATO countries involved in the war in Afghanistan [65], and later changed under the Obama administration, it nonetheless highlights the complex nature of modern conflicts and the challenges facing military physicians in trying to apply the prescriptions of international policies that were written for very different types of warfare. If the decision regarding classification of combatants is made on the advice of "political leadership rather than on objective facts, the potential for undermining the humanitarian impact of International Humanitarian Law increases dramatically" [66, p.158].

Following allegations of prisoner torture by American soldiers and the involvement of medical personnel at Guantanamo Bay, Cuba, and in Iraq and Afghanistan, in 2005 the US Defence Department changed its ethical guidelines for health professionals $[1,25,67]$. These new guidelines, contrary to international humanitarian laws and international or national codes of medical ethics, opened the door for psychiatrists and physicians not involved in the care of prisoners to participate in interrogations. Their involvement was justified by the absence of a clinical link with the prisoners (i.e., the physician-patient relationship). Groups of psychologists and psychiatrists were created with the explicit mandate to develop integrated strategies for interrogation by manipulating prisoners' emotions and weaknesses so that they would provide information to US intelligence services [25]; and this was justified on the basis that these health professionals were not treating patients since they had no relationship with them, but were merely acting as behavioural scientists [24]. Of course, this participation by health personnel has been denounced by many and raised questions about the participation of physicians in war in its broadest sense. But this situation also demonstrates how the notion of patient (within a physician-patient relationship) can become confused and politically charged in a given context. In addition, the fiduciary or trust nature of the physician-patient relationship can be less clear in the context of a military operation because physicians are assigned to specific units and often have little direct contact with the soldiers they are likely to treat [24] $]^{2}$.

Finally, military physicians are asked to work in different contexts such as natural disasters, humanitarian crises and security operations, sometimes side-by-side with non-governmental organisations (NGO) and humanitarian workers. Since the end of the Cold War, conflicts are mostly

\footnotetext{
${ }^{2}$ Most military physicians work in secure base hospitals, some distance from the front lines and active combat operations. By contrast, medics - who are usually not members of formal health professions such as medicine or nursing, and who are combatants (i.e., part of combat teams) - will likely face a different set of professional and ethical conflicts than those faced by military physicians working in base hospitals.
} 
intrastate as opposed to interstate. Military operations are increasingly deployed for humanitarian reasons and for the protection of human rights as opposed to, for example, dominance over territory and resources [68]. But the objectives of such aid - and of the partners involved in delivering aid may be very different. For example, in Afghanistan and Iraq, humanitarian aid was used by the US military to advance military goals [69]. Such situations can create confusion on the part of the public and the health professionals involved in such missions regarding objectives that may, depending on the actor involved, be development, humanitarian and/or military [70-72].

In sum, political decisions (from government or from health professionals) in a military context have the potential to affect the work of health professionals to the point where it can redefine their contribution and role both in the military and towards patients.

This perspective focuses on the broader context, i.e., the social and political roles of physicians within a democratic society. Arguments are made as to whether or not physicians should advocate for peace, against war, or if they have a civic duty to treat the wounded. Although international humanitarian laws seek to preserve medical neutrality and impartiality, the political motivations of governments and their interpretation of these laws can have an impact on the work of military physicians. When discussing issues at this level, one can forget the therapeutic aim of medicine, and politically justify non-therapeutic roles of physicians for military purposes. Hence, the relevance of setting the context when discussing ethical dilemmas in military medicine in order to consider the different roles of physicians (healer, employee, citizen), and the other actors involved (patient, military, government).

\section{Conclusion}

The above review of dilemmas encountered in military medicine shows that they are very often presented as being the result of real or perceived pressures from military or political interests on physicians to divert their professional duty to their patients in favour of other ethical priorities; these pressures will then inevitably create ethical conflicts and contradictions that are difficult to manage. Thus, the state is opposed to the patient in its prioritising of collective interests over individual patient benefit, and the military institution is pitted against the physician in a conflict between, on the one hand, military interest and institutional pressure to conform, and on the other, medical responsibility and autonomy. Basically, there is a tendency to oppose the physician-patient relationship with the interests of other stakeholders, mainly the military institution.

Frequently, questions and dilemmas regarding military physicians focus on one issue at a time, in parallel and segmented ways, with respect to patients, codes of ethics or political ideology. For example, if the focus is on bioethics principles, the context discussed will often be mainly clinical, patient interest will be considered first, and the physician's main role and activity will be that of a healer with strictly therapeutic aims. If, instead, the focus is on ethical codes and obligations, then the institutional and deontological contexts will be emphasised, with attention to issues of the medical profession and its values, the role of physicians as employees of an organization (i.e., dual loyalties), and often within a utilitarian framework that highlights issues of the common good. In cases where social and democratic principles and policies are put forward, the focus is generally more on the role of physicians as citizens, on collective interests and on social and political aspects of medical practice, often arguing for a liberal or communitarian philosophy of medicine. Hence the way to address ethical conflict in military medicine is often reduced to claims that physicians are virtuous professionals with values that are intrinsically good, and therefore that their profession is simply incompatible with the reality of military operations.

But as Figure 1 shows, dilemmas differ substantially by level, context and the actors involved and this should be acknowledged to better situate ethical analyses of the challenges facing military physicians. In confining the debate to an opposition between only two types of actors, much of the discourse on 
ethics in military medicine seems to miss more essential questions, such as: What are the common values and ethics in military medicine? What is the actual bargaining power or influence that physicians have as military officers? And what are the responsibilities of other stakeholders, namely professional associations, the military institution and even the government in supporting the military physician to be and act as a moral agent?

Not all conflicts of value or ethical dilemmas are due to pressures imposed by the institution in the name of military necessity or interest. Physicians are not, by definition, in an adversarial relationship with the military. The potential for conflict exists (and may be inevitable) between different principles, beliefs and values systems that are held by physicians, national/international professional associations, and the institutions in which physicians work [73]. But these various potential dilemmas are due to the different roles of military physicians and the fact that during an armed conflict, they act as healers, members of the military and also as citizens. Military physicians are in a position where they must have a professional responsibility both towards individuals and society [8] and thus must also attend to the common good. As such, the context in which they operate is both clinical, institutional, social and political. In that sense, military medical ethics would benefit from more explicitly taking into account the relationship between all the actors involved, i.e. physician, patient, military institution and society, and recognize that the responsibility for ethical reflection is shared between several actors and stakeholders who are specific but also interdependent. As Gibson and Suh note [15, p.5]:

Military medicine should be a touchstone for principled management of the convergence of healthcare, foreign affairs, and human rights protection. However, this will only happen if the role of physician moves beyond that of merely a provider of medical services, and if physicians can rise to the challenge and assume the role of providing ethical checks and balances against other military leaders. For their part, military commanders must increasingly understand the unique role that physicians and other healthcare professionals play in their units. Physicians are not riflemen who conveniently possess medical skills. They possess highly developed scientific and humanitarian assets and thus may provide a perspective on military operations that other officers cannot.

As suggested by Bloche [7], the challenge for medical ethics is not to resolve all tensions between patient welfare and collective interests, but rather to reflect on how and to what extent the social expectations or pressures placed on physicians can become part of a coherent medical ethics reflection and judgment.

Military medicine, like medicine in general, involves a diverse group of actors and interests and touches on potentially contested views of the role and obligations of physicians, that is, as a caregiver in the patient-physician relationship, but also as a professional with social and political responsibilities. Military medicine is but one example of the larger debate in medical ethics about the appropriate roles and responsibilities of physicians in diverse workplaces [21]. As medical practice has changed over the years, so too have social priorities. For example, issues of resource limitation and physician responsibilities towards society are becoming important constraints in many contexts, not just in military medicine. These types of problems are increasingly being discussed in the public health ethics literature, and in bioethics in general. In fact, a review of the literature by Wendler [74] reveals that there are no less than 27 exceptions recognized by scholars and physicians regarding the primacy of patient's best interests with competing considerations in contemporary medical practice.

I have argued that three perspectives - i.e., individual and clinical (micro), organizational and deontological (meso) and social and political (macro) - are necessary to examine the ethical dilemmas discussed in the literature on military medicine, in order to make progress in addressing the complex reality of military physicians. A larger and more conceptually clear discussion and analysis is thus required regarding the physician's role in society in general, and in war in particular, and one that 
encourages an appropriate sharing of responsibilities between the actors involved (physicians, military institution and government) so as to maintain an ethical climate in the very difficult circumstances of military operations (armed conflict, peacekeeping or even humanitarian missions).

\section{References}

1. Miles SH. Abu Ghraib: its legacy for military medicine. The Lancet. 2004;364(9435):725-9.

2. Allhoff F, editor. Physicians at War: The Dual Loyalty Challenge. New York, NY: Springer; 2008.

3. Pellegrino ED. The moral foundations of the patient-physician relationship: the essence of medical ethics. In: Beam TE, Sparino LR, editors. Military Medical Ethics, Vol 1. Falls Church, VA: Office of the Surgeon General; 2003. p. 3-21.

4. Annas GJ. Military medical ethics - physician first, last, always. New England Journal of Medicine. 2008;359(11):1087-90.

5. Gross ML. Bioethics and Armed Conflict: Moral Dilemmas of Medicine and War. Cambridge, Mass: MIT Press; 2006.

6. Moreno JD. In the Wake of Terror: Medicine and Morality in Time of Crisis. Cambridge, Mass: MIT Press; 2004.

7. Bloche MG. Clinical loyalties and the social purposes of medicine. JAMA. 1999;281(3):268-74.

8. Benatar SR, Upshur REG. Dual loyalty of physicians in the military and in civilian life.

American Journal of Public Health. 2008;98(12):2161-7.

9. London L, Rubenstein LS, Baldwin-Ragaven I, Van Es A. Dual loyalty among military health professionals: human rights and ethics in times of armed conflict. Cambridge Quarterly of Healthcare Ethics. 2006;15:381-91.

10. Singh JA. American physicians and dual loyalty obligations in the "war on terror". BMC Med Ethics. 2003;4(4).

11. Sidel VW, Levy BS. Physician-soldier: a moral dilemma. In: Beam TE, Sparino LR, editors. Military Medical Ethics, Vol 1. Falls Church, VA: Office of the Surgeon General; 2003. p. 293312.

12. Santa Barbara J. Working for peace through health - ethical values and principles. Croatian Medical Journal. 2005;46(6):1007-9.

13. Schmitt MN. Military necessity and humanity in international humanitarian law: preserving the delicate balance. Virginia Journal of International Law. 50(4):796-837.

14. Madden W, Carter B. Physician-soldier: a moral profession. In: Beam TE, Sparino LR, editors. Military Medical Ethics, Vol 1. Falls Church, VA: Office of the Surgeon General; 2003. p. 26991.

15. Gibson BR, Suh R. Doctors with borders: the role of health professionals in war and human rights. Medscape Public Health. 2007.

16. Gross ML. Military medical ethics: a review of the literature and a call to arms. Cambridge Quarterly of Healthcare Ethics. 2013;22:92-109.

17. Canli T, Brandon S, Casebeer W, Crowley PJ, DuRousseau D, Greely HT, Pascual-Leone A. Neuroethics and national security. American Journal of Bioethics. 2007;7(5):3-13.

18. Durand G. Introduction générale à la bioéthique: histoire, concepts et outils. Les Editions Fides; 2005. $580 \mathrm{p}$.

19. Drane JF. What is bioethics? A history. In: Lolas FS, Agar LC, eds. Interfaces Between Bioethics and the Empirical Social Sciences [Regional program on bioethics OPS/OMS publication series 2002]. Third Meeting of the International Advisory Board on Bioethics. Buenos Aires: Pan American Health Organization and WHO; October 2001; 15-32.

20. Schapowal AG, Baer H-U. Medical ethics in peace and in the armed conflict. Military Medicine. 2002 Aug;167(8 Suppl):26-31.

21. Howe EG. Point/Counterpoint-A response to Drs Sidel and Levy. In: Beam TE, Sparino LR, editors. Military Medical Ethics, Vol 1. Falls Church, VA: Office of the Surgeon General; 2003. p. 312-20. 
22. Moran P. A military exception to "informed consent": Doe v. Sullivan. St John's Law Review. 2012;66(3), article 15.

23. Wynia MK. Breaching confidentiality to protect the public: evolving standards of medical confidentiality for military detainees. American Journal of Bioethics. 2007;7:1-5.

24. Frisina ME. Guidelines to prevent the malevolent use of physicians in war. In: Allhoff $F$, editor. Physicians at War: The Dual Loyalty Challenge. New York, NY: Springer; 2008. p. 39-52.

25. Miles SH. Oath Betrayed: America's Torture Doctors. 2nd ed. Los Angeles, CA: University of California Press; 2009.

26. Childress JF. Conclusions and Next Steps. In: Military Medical Ethics: Issues Regarding Dual Loyalties: Workshop Summary. Washington, DC: The National Academies Press; 2008. p. 3336.

27. World Medical Association. WMA Regulations in Times of Armed Conflict and Other Situations of Violence. 2012 (1956).

28. The Geneva Hippocratic Oath. Journal of the National Medical Assocation. 1949;41(5):225-6.

29. Miles SH. The new military medical ethics: legacies of the gulf wars. Bioethics. 2011;27(3):117-23.

30. Hathout $L$. The right to practice medicine without repercussions: ethical issues in times of political strife. Philosophy, Ethics, and Humanitarian Medicine. 2012;7(11).

31. 1949 Geneva Convention (I) for the Amelioration of the Condition of the Wounded and Sick in Armed Forces in the Field. Centre for International Law.

32. Gross ML. Why treat the wounded? Warrior care, military salvage, and national health. American Journal of Bioethocs. 2008;8:3-12.

33. Swan KG, Swan KG jr. Triage: the past revisited. Military Medicine. 1996;161(8):448-52.

34. Repine TB, Lisagor $P$, Cohen DJ. The dynamics and ethics of triage: rationing care in hard times. Military Medicine. 2005;170(6):505-9.

35. Rawling B. La mort pour ennemi : La médecine militaire canadienne. Ottawa, Canada: Agmv; 2008.

36. Beckett A, Pelletier P, Mamczak C, Benfield R, Elster E. Multidisciplinary trauma team care in Kandahar, Afghanistan: Current injury patterns and care practices. Injury. 2012;43(12):2072-7.

37. Kondro W. Afghanistan: Outside the comfort zone in a war zone. CMAJ. 2007;177(2):131-4.

38. Gordon S. The military physician and contested medical humanitarianism: a dueling identity? Social Science and Medicine. 2014;120:421-9.

39. Sokol DK. The medical ethics of the battlefield. BMJ. 2011;343(3):d3877.

40. Tobin J. The challenges and ethical dilemmas of a military medical officer serving with a peacekeeping operation in regard to the medical care of the local population. Journal of Medical Ethics. 2005;31:571-4.

41. Okie S. Glimpses of Guantanamo - medical ethics and the war on terror. New England Journal of Medicine. 2005;353(24):2529-34.

42. Koch T. Weaponising medicine: "Tutti fratelli," no more. Journal of Medical Ethics. 20061;32(5):249-55.

43. Wang $T$. Towards a military medical ethics framework for genetic human enhancement. Penn Bioethics Journal. 2010;6(1):8-12.

44. Bloche MG, Marks JH. When doctors go to war. New England Journal of Medicine. 20056;352(1):3-6.

45. United Nations. The Universal Declaration of Human Rights. New York; 1948.

46. United Nations. International Legal Protection of Human Rights in Armed Conflict. New York; 2011. 119 p.

47. Giannou C, Baldan M. War surgery: working with limited resources in armed conflict and other situations of violence. ICRC; 2009. $351 \mathrm{p}$.

48. Darre É. Droit international humanitaire : problèmes éthiques posés au médecin. Université Aix-Marseille II - Attestation d'éthique médicale. 2002.

49. lacopino V, Waldman RJ. War and health: From Solferino to Kosovo - the evolving role of physicians. JAMA. 1999;282(5):479-81. 
50. Sidel VW, Levy BS. War, terrorism, and public health. Journal of Law, Medicine \& Ethics. 2003;31(4):516-23.

51. Gross ML. Is medicine a pacifist vocation or should doctors help build bombs. In: Allhoff F, editor. Physicians at War: The Dual Loyalty Challenge. New York, NY: Springer; 2008. p. 1516.

52. American Medical Association. Principles of Medical Ethics. 2001 (1957).

53. Horton R. Public health: a neglected counterterrorist measure. The Lancet. 2001;358:1112-3.

54. Levy BS, Sidel VW, editors. War and Public Health. Oxford University Press; 1997. 444 p.

55. Murray CJL, King G, Lopez AD, Tomijima N, Krug EG. Armed conflict as a public health problem. BMJ. 2002;324(7333):346-9.

56. MacQueen G, Santa-Barbara J, Neufeld V, Yusuf S, Horton R. Health and peace: time for a new discipline. The Lancet. 2001;357(9267):1460-1.

57. Wass V. Doctors in society: medical professionalism in a changing world. Clinical Medicine. 2006;6(1):109-13.

58. Zwi AB. How should the health community respond to violent political conflict? PLoS Medicine. 2004;1(1):e14.

59. Pinto AD. Peace through health. University of Toronto Medical Journal. 2003;80(2):158-60.

60. List JM. Medical neutrality and political activism: physicians' roles in conflict situations. In: Allhoff F, editor. Physicians at War: The Dual Loyalty Challenge. New York, NY: Springer; 2008. p. 237-53.

61. Rascona D. The moral obligation of United States Military Medical Service. In: Beam TE, Sparino LR, editors. Military Medical Ethics, Vol 1. Falls Church, VA: Office of the Surgeon General; 2003. p. 320-5.

62. Baril D. Les principes de la guerre juste peuvent-ils s'appliquer au terrorisme? Forum. 2008.

63. Howe EG. Dilemmas in military medical ethics since 9/11. Kennedy Institute of Ethics Journal. 2003;13(2):175-88.

64. Bush GW. Memorandum: Humane Treatment of Al Queda and Taliban Detainees. US Government: Washington, D.C.; 2002.

65. Elsea J. Treatment of "battlefield detainees" in the war on terrorism. Congressional Research Service; 2005.

66. Carswell A. Classifying the conflict: A soldier's dilemma. International Review of the Red Cross. 2009;91(873):143-161.

67. Rubenstein L, Pross C, Davidoff F, lacopino V. Coercive us interrogation policies: A challenge to medical ethics. JAMA. 2005 Sep 28;294(12):1544-9.

68. Schweizer B. Moral dilemmas for humanitarianism in the era of "humanitarian" military interventions. International Review of the Red Cross. 2004;86(855):547-64.

69. Lischer SK. Military intervention and the humanitarian "force multiplier". Global Governance. 2007;13(1):99-118.

70. Désilets L-P. La contribution du Canada à la reconstruction de l'Afghanistan : une mise en application du concept de "sécurité humaine". Points de mire. 2004;5(6):1-2.

71. Duffield M. Global Governance and the New Wars: The Merging of Development and Security. London: Zed Books; 2001.

72. Nossal KR. "The world we want"?: The purposeful confusion of values, goals, and interests in Canadian foreign policy. Ottawa, ON: Canadian Defence and Foreign Affairs Institute; 2003.

73. Pearce G, Saul P. Toward a framework for military health ethics. In: Allhoff F, editor. Physicians at War: The Dual Loyalty Challenge. New York, NY: Springer; 2008. p. 75-88.

74. Wendler D. Are physicians obligated always to act in the patient's best interests? Journal of Medical Ethics. 2010 Feb 1;36(2):66-70. 